\title{
Index of Inscriptions
}

$\begin{array}{ll}\text { CIL II Suppl. 1143 } & 166 \mathrm{n} .110 \\ \text { CIL VIII 24585a } & 239 \mathrm{n} .18 \\ \text { CIL XIII 1668 } & 203 \\ \text { Tabual Hebana 1-4 } & 265 \\ \text { Tabula Siarensis lic 13-17 } & 265\end{array}$


